\title{
Extending vase life of carnation flowers by postharvest nano silver, humic acid and Aloe Vera gel treatments
}

\author{
Asmaa Bader El-din Sayed El-Attar ${ }^{1 *}$ (]), Weaam Ramadan Arafa Sakr ${ }^{1}$ (]) \\ ${ }^{1}$ Cairo University, Faculty of Agriculture, Department of Ornamental Horticulture, Giza, Egypt.
}

\begin{abstract}
Standard Carnation flowers (Dianthus caryophyllus cv. Dover) were harvested at the paint brush stage in the early morning, pre-cooled at $4{ }^{\circ} \mathrm{C}$ for 6-h then moved under dry conditions to the laboratory. Flowers were weighted and treated for 24-h with silver nanoparticles (AgNPs) at 0,5 or $10 \mathrm{ppm}$ in plastic buckets. After pulsing treatments, cut flowers were transferred to $500 \mathrm{~mL}$ glass jars containing $300 \mathrm{~mL}$ of preservation solution treatments including, individually, humic acid at 200, 400 or $600 \mathrm{ppm}$ and Aloe vera gel at $2.5 \%, 5.0 \%$ or $7.5 \%(\mathrm{w} / \mathrm{v})$ till the end of the experiment (when flower color began to fade, petals began to roll). Distilled water was used for the control and to prepare the tested solutions. $2 \%$ sucrose was added to all treatments including the control. Addition of all preservatives to vase solutions significantly increased all the studied characteristics of cut flowers compared to control (distilled water, least values). Nanosilver treatments have the potential to be used as preservative solutions for improving postharvest vase life and quality of carnation flowers. An increment in vase life, relative fresh weight, vase solution uptake, flower diameter as well as total chlorophylls in leaves, total carbohydrates and total phenols in leaves and petals was observed, in addition to a decrease in bacterial counts in vase solution. Best results were obtained using $5 \mathrm{ppm}$ AgNPs $+5.0 \%$ Aloe vera gel followed by $5 \mathrm{ppm}$ AgNPs $+7.5 \%$ Aloe vera gel solutions. Aloe vera gel, especially $5.0 \%$ level, showed better results than humic acid when used alone or combined with AgNPs. Nanosilver at $5 \mathrm{ppm}$ recorded better results than $10 \mathrm{ppm}$ when used as a single treatment.
\end{abstract}

Keywords: Dianthus caryophyllus cv. Dover, silver nanoparticles, durability, floriculture, sucrose.

\section{Resumo}

Prolongando a vida de vaso das flores de cravo com tratamentos pós-colheita de nano-prata, ácido húmico e gel de Aloe vera

Flores de cravo (Dianthus caryophyllus cv. Dover) foram colhidas no estádio de pincel no início da manhã, pré-resfriadas a 4 ${ }^{\circ} \mathrm{C}$ por 6 horas e então movidas a seco para o laboratório. As flores foram pesadas e tratadas por 24 horas com nanopartículas de prata (AgNPs) a 0, 5 ou $10 \mathrm{ppm}$ em baldes plásticos. Após os tratamentos de plusing, as flores cortadas foram transferidas para frascos de vidro de $500 \mathrm{~mL}$ contendo $300 \mathrm{~mL}$ de solução de preservação incluindo, individualmente, ácido húmico a 200, $400 \mathrm{ou}$ $600 \mathrm{ppm}$ e gel de Aloe vera a 2,5\%,5.0\% ou 7,5\% até o final do experimento (quando a cor da flor começou a desbotar, as pétalas começaram a enrolar). Água destilada foi utilizada para o controle e preparação das soluções testadas. Sacarose $2 \%$ foi adicionada a todos os tratamentos, incluindo o controle. A adição de todos os conservantes às soluções de vaso aumentou significativamente características estudadas em relação ao controle (água destilada, valores mínimos). Os tratamentos com nanopartículas de prata têm potencial para serem usados como soluções conservantes para melhorar a vida de vaso e a qualidade das flores de cravo. Observou-se incremento na vida de vaso, massa fresca relativa, absorção de solução de vaso, diâmetro das flores e clorofilas totais nas folhas, carboidratos totais e fenóis totais nas folhas e pétalas, além de diminuição na contagem bacteriana na solução de vaso. Os melhores resultados foram obtidos utilizando $5 \mathrm{ppm}$ de AgNPs $+5.0 \%$ de gel de Aloe vera seguido por $5 \mathrm{ppm}$ de AgNPs $+7.5 \%$ de soluções de gel de Aloe vera. O gel de Aloe vera, especialmente o nível de 5\%, mostrou melhores resultados do que o ácido húmico quando usado sozinho ou combinado com AgNPs. Nanosilver a 5 ppm registrou resultados melhores do que 10 ppm quando usado como um único tratamento.

Palavras-chave: Dianthus caryophyllus cv. Dover, nanopartículas de prata, durabilidade, floricultura, sacarose.

\footnotetext{
*Corresponding author: asmaa.said@agr.cu.edu.eg
} 


\section{Introduction}

Carnation (Dianthus caryophyllus L.) belongs to family Caryophyllaceae and it has an important commercial value and widely cultivated for its showy, variously colored and fragrant flowers as cut flowers for ornamental purposes or in gardens. It is native to the Mediterranean region (Yagi et al., 2020). Carnation is classified as standard or spray type. The standard type has only one flower per stem, and the spray type has multiple flowers per stem (Boxriker et al., 2018). Carnation is very sensitive to ethylene and it is synthesized in high portions after the full flower opening (Darqui et al., 2017). Vase life of carnation flowers is short, almost seven days without using floral preservative solution (Aalifar et al., 2020). Hormonal control of ethylene significantly prolongs carnation vase life and delays senescence. When ethylene production rises, respiration and polyribosome activity increase and specific genes become depressed and protein molecules degrade (Wu et al., 2017). Prolonged vase life is an important parameter for valuing perishable cut flower quality. Thus, it is crucial to use natural and effective preservative compounds in this respect for domestic and large scale applications.

Nano-sized materials are more active than those of large particles because of high surface area to volume ratio. Silver nanoparticles have been reported to be effective as an antimicrobial agent against bacteria, viruses and other eukaryotic microorganisms (Wang et al., 2017). Silver nanoparticles destroy the bacterial cells by penetrating their membranes and inhibiting respiratory chain enzymes and cell division. $\mathrm{Ag}^{+}$as a heavy metal ion causes cellular oxidative stress in microbes (Qing et al., 2018). Nanosilver enhanced vase life and morpho-physicological and chemical characteristics of carnation and inhibits bacterial growth and blockage in stem segments, besides it acts as an anti-ethylene agent (Park et al., 2017; Naing et al., 2017; Rashidiani et al., 2020). Postharvest quality of some cut flowers such as chrysanthemum and rose was significantly improved and their vase life, exhibited higher activity of superoxide dismutase, senescence delay, enhanced chlorophyll content and growth of the bacteria significantly decreased by application of nanosilver (Kazemipour et al., 2016 ; Naing and Kim, 2020; Bayanati et al., 2021).

Application of humic acid induces catalases as antioxidative defense mechanisms. Also, it preserves the carbohydrate accumulation status of flowers and stems leading to offering substrate for respiration and reducing sensitivity to ethylene as well. Humic acid preservative solutions improved vase life, flower size, flower fresh weight, increased chlorophyll content, and rate of photosynthesis contents in chrysanthemum (Fan et al., 2015; Vehniwal and Abbey, 2019).

Aloe vera gel is a natural ingredient containing polysaccharides, fatty acids, amino acids, vitamins, minerals, and seven superoxide dismutase with antioxidant activity and six antiseptic agents against fungi, bacteria and viruses, salicylic acid, urea nitrogen, cinnamonic acid, phenols and sulfur (Bharadwaj, et al., 2018). Aloin and aloe-emodin the major anthraquinones in aloe may be responsible for its anti-inflammatory effects as they contain a polyphenolic structure. Aloe vera gel improved vase life, water uptake, and relative water content of Heliconia cut flowers (Shokalu et al., 2019).

The aim of this study was to evaluate the efficacy of silver nanoparticles, humic acid and Aloe vera gel in extending the vase-life of carnation flowers.

\section{Material and Methods}

Carnation flowers (Dianthus caryophyllus cv. Dover) were obtained from Floramix, a commercial Farm in Kafr Hakim, Giza. On 25 ${ }^{\text {th }}$ April in both seasons of 2017 and 2018, the standard flowers were harvested at the paint brush stage in the early morning. The cut flowers were pre-cooled at 4 ${ }^{\circ} \mathrm{C}$ for 6-h to remove the effect of high temperature in the field, then they were wrapped in Kraft paper in bunches and moved (for one hour ) under dry conditions to the laboratory where the temperature was $25 \pm 2{ }^{\circ} \mathrm{C}$, relative humidity was $40 \%$ and light intensity was 1800 lux. Flowering stems were cut to length of $35 \mathrm{~cm}$. Flowers were weighed and treated with pulsing for 24-h with silver nanoparticles (AgNPs) at 0,5 or $10 \mathrm{ppm}$ in three liters plastic buckets. Silver nanoparticles were obtained from Nano Tech Egypt Company. After pulsing, cut flowers of each treatment were transferred to $500 \mathrm{~mL}$ glass jars containing $300 \mathrm{~mL}$ of preservation solution treatments including, individually, humic acid (Humate UAD, obtained from Egyptian Group for Development Giza, Egyp) at 200, 400 or $600 \mathrm{ppm}$ and Aloe vera gel (the gel extract was obtained from freshly harvested Aloe vera plants from the floriculture garden) at $2.5 \%, 5.0 \%$ or $7.5 \%\left(\mathrm{w} \mathrm{v}^{-1}\right)$ till the end of the experiment (flower color began to fade, petals began to roll). Distilled water was used for the control and to prepare the tested solutions. $2 \%$ sucrose was added to all treatments including the control treatment.

\section{Data recorded}

Vase life and quality determinations:

- Vase life (days): The vase life of each flower was determined by counting number of days from cutting until the petals showed the visible symptoms of senescence (such as wilting, loss, discoloration of petals, stems shrinkage, brown edges and yellow/brown foliage).

-Relative Fresh weight: Cut flowers were fresh weighed before immersing in keeping solutions. Thereafter, flowers were weighted at the end of the vase life and expressed relatively to their initial weights.

- Vase solution uptake (mL/flower/day): Solution uptake was determined by subtracting the volume of water evaporated from the glass jars containing flowers of the same volume without cut flowers from the beginning of the experiment till the senescence.

-Flower diameter (cm): Flower diameter was measured daily with a Vernier-caliper. The maximum flower diameter was recorded to indicate efflorescence of flower. 


\section{Bacterial counts in vase solution $\left(\mathrm{CFU} \mathrm{mL} \mathrm{m}^{-1}\right)$}

The vase solutions used for standing carnation flowering stems were sampled and incubated at $30{ }^{\circ} \mathrm{C}$ for 48-72 hours. The total viable count of bacterial cells in vase solution was assessed by dilution plate method for the numeration of microorganisms on standard plate count agar medium (ISO 4833-1, 2013). The bacterial cells count was recorded on the ninth day of vase life for all treatments as it was the last day for control vase life.

\section{Transmission electron microscope (TEM)}

At the end of control vase life, two specimens of 0.5 $\mathrm{cm}$ in length and thickness were taken from the bases of carnation flowering stems from each treatment. Samples were processed and examined by transmission electron microscope JEOL (JEM-1400 TEM) (Bozzola and Russell, 1999) in TEM lab, Faculty of Agriculture, Cairo University, Research Park FA-CURP.

\section{Anatomical studies}

Specimens (1 cm long) from the bases of carnation flowering stems were obtained from various treatments at the end of the control vase life. The microtechnique procedures were carried out at Faculty of Agriculture, Cairo University, Research Park FA-CURP (Nassar and ElSahhar, 1998). The prepared slides were microscopically examined, and mean values of the studied traits (diameter of the whole section, thickness of tissues outside the vascular cylinder, thickness of the vascular cylinder, diameter of the xylem vessel and diameter or bith) were detected as an average of readings from three slides per treatment.

\section{Chemical analysis}

At the end of the study, contents of total chlorophylls in fresh leaves (mg $100 \mathrm{~g} \mathrm{FW}^{-1}$ ) (Nornai, 1982) and total carbohydrates in fresh petals and leaves (\%) (Dubois et al., 1956) were determined. Total phenols (\%) in fresh petals and leaves were determined colorimetrically according to the Folin-Ciocalteu colorimetric method (Singleton and Rossi, 1965).

\section{Statistical analysis}

This experiment was conducted using a randomized complete blocks design with three replicates, and there were three cut flowers in each replicate. The data collected were subjected to a statistical analysis of variance (ANOVA), and the means were compared using the "Least Significant Difference (L.S.D.)" test at the 5\% level, as described by Little and Hills (1978).

\section{Results and Discussion}

\section{Vase life and quality determinations:}

Data presented in Tables 1and 2 revealed that, in general, the control treatment gave the lowest values for vase life, relative fresh weight, vase solution uptake and flower diameter compared to the control. 
Table 1. Effect of nanosilver, humic acid and Aloe vera gel on vase life, relative fresh weight and vase solution uptake of carnation cut flowers during two seasons.

\begin{tabular}{|c|c|c|c|c|c|c|c|}
\hline \multicolumn{2}{|c|}{ Treatments } & \multicolumn{2}{|c|}{ Vase life (day) } & \multicolumn{2}{|c|}{ Relative fresh weight (\%) } & \multicolumn{2}{|c|}{$\begin{array}{l}\text { Vase solution uptake } \\
\text { (mL/flower/day) }\end{array}$} \\
\hline Nanosilver & $\begin{array}{l}\text { Humic acid and } \\
\text { Aloe vera gel }\end{array}$ & $1^{\text {st }}$ season & $2^{\text {nd }}$ season & $1^{\text {st }}$ season & $2^{\text {nd }}$ season & $1^{\text {st }}$ season & $2^{\text {nd }}$ season \\
\hline \multirow[t]{7}{*}{ N0 (control) } & & 9.36 & 9.00 & 0.92 & 0.95 & 5.00 & 5.66 \\
\hline & $\mathrm{H} 1$ & 10.89 & 10.15 & 1.02 & 1.08 & 7.33 & 6.67 \\
\hline & $\mathrm{H} 2$ & 11.05 & 10.78 & 1.03 & 1.09 & 7.00 & 7.33 \\
\hline & $\mathrm{H} 3$ & 10.45 & 10.00 & 1.00 & 1.05 & 6.33 & 5.83 \\
\hline & A1 & 11.61 & 11.00 & 1.03 & 1.13 & 7.00 & 6.67 \\
\hline & $\mathrm{A} 2$ & 12.00 & 11.00 & 1.07 & 1.14 & 9.33 & 6.67 \\
\hline & A3 & 18.00 & 11.00 & 1.14 & 1.12 & 8.50 & 6.16 \\
\hline \multirow[t]{7}{*}{ N5 } & & 12.10 & 12.00 & 1.17 & 1.08 & 7.53 & 10.33 \\
\hline & $\mathrm{H} 1$ & 14.61 & 16.00 & 1.14 & 1.16 & 8.17 & 11.66 \\
\hline & $\mathrm{H} 2$ & 18.74 & 18.01 & 1.18 & 1.10 & 8.17 & 10.67 \\
\hline & H3 & 16.48 & 14.60 & 1.16 & 1.07 & 10.01 & 11.83 \\
\hline & A1 & 18.06 & 18.00 & 1.18 & 1.08 & 10.00 & 12.66 \\
\hline & $\mathrm{A} 2$ & 18.75 & 20.60 & 1.22 & 1.30 & 12.53 & 13.60 \\
\hline & A3 & 18.00 & 18.85 & 1.21 & 1.17 & 12.00 & 13.00 \\
\hline \multirow[t]{7}{*}{ N10 } & & 11.01 & 10.05 & 1.02 & 1.09 & 9.30 & 9.57 \\
\hline & $\mathrm{H} 1$ & 13.30 & 12.30 & 1.07 & 1.16 & 7.83 & 10.00 \\
\hline & $\mathrm{H} 2$ & 14.60 & 15.30 & 1.03 & 1.12 & 8.51 & 12.33 \\
\hline & $\mathrm{H} 3$ & 13.30 & 13.30 & 1.05 & 1.06 & 12.07 & 11.83 \\
\hline & A1 & 16.00 & 16.00 & 1.08 & 1.06 & 9.83 & 12.67 \\
\hline & A2 & 18.00 & 18.00 & 1.03 & 1.11 & 11.39 & 12.51 \\
\hline & A3 & 17.30 & 16.6 & 1.04 & 1.08 & 10.52 & 9.67 \\
\hline \multicolumn{2}{|c|}{ L.S.D. (0.05) } & 1.54 & 1.75 & 0.11 & 0.19 & 1.04 & 1.23 \\
\hline
\end{tabular}

N0, N5 and N10: nanosilver at 0, 5 and 10 ppm, respectively. H1, H2 and H3: humic acid at 200, 400 and 600 ppm, respectively. A1, A2 and A3: Aloe vera gel at $2.5 \%, 5.0 \%$ and $7.5 \%$ respectively. 
Table 2. Effect of nanosilver, humic acid and Aloe vera gel on flower diameter and bacterial counts in vase solution of carnation cut flowers during two seasons.

\begin{tabular}{|c|c|c|c|c|c|}
\hline \multicolumn{2}{|r|}{ Treatments } & \multicolumn{2}{|c|}{ Flower diameter (cm) } & \multicolumn{2}{|c|}{ Bacterial counts in vase solution $(\mathrm{CFU} / \mathrm{mL})$} \\
\hline Nanosilver & Humic acid and Aloe vera gel & $1^{\text {st }}$ season & $2^{\text {nd }}$ season & $1^{\text {st }}$ season & $2^{\text {nd }}$ season \\
\hline \multirow[t]{7}{*}{ N0 (control) } & & 7.81 & 5.03 & $2.3 \times 10^{8}$ & $1.6 \times 10^{8}$ \\
\hline & $\mathrm{H} 1$ & 9.83 & 6.35 & $3.3 \times 10^{7}$ & $2.5 \times 10^{7}$ \\
\hline & $\mathrm{H} 2$ & 9.73 & 6.95 & $6.4 \times 10^{7}$ & $5.1 \times 10^{6}$ \\
\hline & $\mathrm{H} 3$ & 8.58 & 6.02 & $8.6 \times 10^{7}$ & $5.3 \times 10^{7}$ \\
\hline & A1 & 10.16 & 7.06 & $9.3 \times 10^{6}$ & $6.3 \times 10^{7}$ \\
\hline & $\mathrm{A} 2$ & 9.00 & 8.85 & $1.8 \times 10^{6}$ & $4.0 \times 10^{6}$ \\
\hline & A3 & 8.71 & 6.20 & $1.4 \times 10^{6}$ & $3.0 \times 10^{6}$ \\
\hline \multirow[t]{7}{*}{ N5 } & & 8.18 & 6.92 & $4.7 \times 10^{7}$ & $6.0 \times 10^{6}$ \\
\hline & $\mathrm{H} 1$ & 9.12 & 7.84 & $4.6 \times 10^{6}$ & $2.5 \times 10^{6}$ \\
\hline & $\mathrm{H} 2$ & 9.11 & 9.74 & $2.2 \times 10^{7}$ & $1.4 \times 10^{6}$ \\
\hline & H3 & 8.34 & 8.28 & $2.1 \times 10^{7}$ & $1.8 \times 10^{7}$ \\
\hline & A1 & 9.74 & 7.56 & $1.2 \times 10^{6}$ & $5.3 \times 10^{6}$ \\
\hline & $\mathrm{A} 2$ & 10.20 & 10.03 & $1.2 \times 10^{5}$ & $2.8 \times 10^{5}$ \\
\hline & A3 & 9.52 & 8.52 & $2.0 \times 10^{6}$ & $1.7 \times 10^{6}$ \\
\hline \multirow[t]{7}{*}{ N10 } & & 9.11 & 9.38 & $1.3 \times 10^{7}$ & $1.0 \times 10^{7}$ \\
\hline & $\mathrm{H} 1$ & 9.98 & 8.27 & $3.7 \times 10^{7}$ & $2.0 \times 10^{7}$ \\
\hline & $\mathrm{H} 2$ & 8.43 & 8.73 & $6.5 \times 10^{6}$ & $6.5 \times 10^{6}$ \\
\hline & $\mathrm{H} 3$ & 8.90 & 9.52 & $1.0 \times 10^{7}$ & $1.6 \times 10^{7}$ \\
\hline & A1 & 7.73 & 9.47 & $2.5 \times 10^{7}$ & $1.7 \times 10^{7}$ \\
\hline & $\mathrm{A} 2$ & 9.74 & 9.38 & $3.6 \times 10^{6}$ & $7.0 \times 10^{6}$ \\
\hline & $\mathrm{A} 3$ & 7.88 & 8.27 & $8.8 \times 10^{6}$ & $6.8 \times 10^{6}$ \\
\hline L.S.D. (0.05) & & 0.42 & 0.36 & & \\
\hline
\end{tabular}

N0, N5and N10: nanosilver at 0, 5 and 10 ppm, respectively.H1, H2 and H3: humic acid at 200, 400 and 600 ppm, respectively.A1, A2 and A3: Aloe vera gel at $2.5 \%, 5.0 \%$ and $7.5 \%$ respectively.

Aloe vera gel at $2.5 \%, 5.0 \%$ or $7.5 \%$ mostly improved vase life, relative fresh weight, vase solution uptake and flower diameter than those recorded with humic acid (200, 400 or $600 \mathrm{ppm}$ ). Application of nanosilver (5 or $10 \mathrm{ppm}$ ) with Aloe vera gel $(2.5 \%, 5.0 \%$ or $7.5 \%)$ as combined treatments showed an improvement in the vase life, relative fresh weight, vase solution uptake and flower diameter than that recorded with the same nanosilver rates and humic acid $(200,400$ or $600 \mathrm{ppm})$. Also, it is worth to mention that the application of $5 \mathrm{ppm}$ nanosilver + Aloe vera gel $(2.5 \%$, $5.0 \%$ or $7.5 \%)$ or humic acid $(200,400$ or $600 \mathrm{ppm})$ was more effective in improving vase life, relative fresh weight and vase solution uptake as compared to application of 10 ppm nanosilver + Aloe vera gel $(2.5 \%, 5.0 \%$ or $7.5 \%)$ or humic acid (200, 400 or $600 \mathrm{ppm})$. The treatment including 5 ppm AgNPs and 5\% Aloe vera gel had an improving effect on vase life, relative fresh weight, vase solution uptake and flower diameter with significant differences in most cases, followed by 5 ppm AgNPs ${ }^{+}$7.5\% Aloe vera gel treatment.

The long vase life of cut flowers might be caused by reducing water stress in association with a high water uptake due to suppressing growth of microbes and blockage of xylem vessels, water loss reduction with inhibition of ethylene evolution and decreasing the transpiration rate leading to controlling the cellular turgor. Production of $\mathrm{Ag}^{+}$ions might inhibit the rise of ethylene precursor. Present results agree with a previous study that found an increase in vase life due to nanosilver treatment (Naing and Kim, 2020).

\section{Bacterial counts in vase solution:}

Control treatment containing distilled water had the highest bacterial counts in vase solution compared with other treatments. An inhibition on bacteria growth was recorded by applying nanosilver at 5 or $10 \mathrm{ppm}$ as compared to the control. The combined treatment including $5 \mathrm{ppm}$ AgNPs and 5\% Aloe vera gel showed superior antibacterial substance and recorded the lowest bacterial counts in vase solution compared with other treatments.

Using Aloe vera gel $(2.5 \%, 5.0 \%$ or $7.5 \%)$ as a single treatment decreased bacterial counts in vase solution than those recorded with humic acid (200, 400 or $600 \mathrm{ppm})$. Application of nanosilver at 5 or $10 \mathrm{ppm}+$ Aloe vera gel at $2.5 \%, 5.0 \%$ or $7.5 \%$ decreased bacterial counts in vase solution than those recorded with the application of nanosilver (5 or $10 \mathrm{ppm})+$ humic acid (200, 400 or 600 ppm). Also, it is worth to mention that the application of $5 \mathrm{ppm}$ nanosilver + Aloe vera gel at $2.5 \%, 5.0 \%$ or 
$7.5 \%$ or humic acid treatments at 200,400 or $600 \mathrm{ppm}$ as combinations was more effective in decreasing bacterial counts than that recorded to application of $10 \mathrm{ppm}$ nanosilver + Aloe vera gel at $2.5 \%, 5.0 \%$ or $7.5 \%$ or humic acid at 200,400 or $600 \mathrm{ppm}$.

The treatment including $5 \mathrm{ppm}$ AgNPs and 5.0\% Aloe vera gel had the highest beneficial effect on decreasing bacterial counts as a superior antibacterial substance. Nano silver succeeded as a biocide suppressing bacterial growth causing less vessel blockage in flowering stem segments leading to promoting water uptake through vascular system and therefore decreasing hydraulic resistance and water stress. Bacteria reduces water uptake and thus vase life is reduced (Schouten et al., 2018). Silver substituted copper which is involved in enzymatic reactions related to biosynthesis of ethylene ( $\mathrm{Li}$ et al., 2017a). Adding silver may prevent ethylene production or decrease ethylene molecules connection to their receptors (Schaller and Binder, 2017). Nano-silver inhibits ethylene production by suppressing the transcript levels of ethylene biosynthesis genes, ACS and ACO, involved in ethylene synthesis which causes leaf yellowing and increase bud opening. Nanosilver pulse reduces stomatal aperture and inhibited leaf transpiration (Naing et al., 2017). Prior studies on cut flowers showed that nanosilver increased vase life, solution uptake, cell membrane permeability, chlorophyll content and inhibit ethylene biosynthesis, microbial growth in cut flowers (Kazemipour et al.,_2016; Li et al.,_2017b; Naing and Kim, 2020).

\section{Chemical analysis}

Data presented in Tables 3 and 4 revealed that the control treatment gave the lowest values of total chlorophylls in fresh leaves, total carbohydrates in fresh leaves and petals as well as total phenols in fresh leaves and petals of carnation cut flowers with most significant differences as compared with other treatments in both seasons. Data indicated that the combined treatments of nanosilver ( 5 ppm) with Aloe vera gel (5.0\%) or nanosilver (5 and 10 ppm) with humic acid (400 ppm) affected positively all the studied characters in both seasons with no significant differences between their effects.

Table 3. Effect of nanosilver, humic acid and Aloe vera gel on total chlorophylls in fresh leaves, total carbohydrates in fresh leaves and petals of carnation cut flowers during two seasons.

\begin{tabular}{|c|c|c|c|c|c|c|c|}
\hline \multicolumn{2}{|c|}{ Treatments } & \multicolumn{2}{|c|}{$\begin{array}{l}\text { Total chlorophylls in fresh leaves } \\
\text { (mg/100 } \mathrm{g} \mathrm{FW})\end{array}$} & \multicolumn{2}{|c|}{$\begin{array}{l}\text { Total carbohydrates in } \\
\text { fresh leaves }(\%)\end{array}$} & \multicolumn{2}{|c|}{$\begin{array}{l}\text { Total carbohydrates in } \\
\text { fresh petals }(\%)\end{array}$} \\
\hline Nanosilver & $\begin{array}{l}\text { Humic acid and } \\
\text { Aloe vera gel }\end{array}$ & $1^{\text {st }}$ season & $2^{\text {nd }}$ season & $1^{\text {st }}$ season & $2^{\text {nd }}$ season & $1^{\text {st }}$ season & $2^{\text {nd }}$ season \\
\hline No & control & 1.13 & 1.09 & 22.00 & 20.00 & 15.03 & 16.32 \\
\hline H1 & & 1.33 & 1.23 & 24.69 & 20.33 & 18.17 & 18.11 \\
\hline $\mathrm{H} 2$ & 1.40 & 1.24 & 24.91 & 22.01 & 15.40 & 17.91 & \\
\hline $\mathrm{H} 3$ & 1.30 & 1.24 & 23.34 & 20.03 & 17.36 & 18.12 & \\
\hline A1 & 1.34 & 1. 12 & 24.89 & 20.06 & 19.20 & 18.10 & \\
\hline $\mathrm{A} 2$ & 1.35 & 1.28 & 24.84 & 22.14 & 18.13 & 18.36 & \\
\hline A3 & 1.38 & 1.26 & 25.14 & 20.47 & 18.10 & 18.13 & \\
\hline N5 & & 1.43 & 1.48 & 24.57 & 21.10 & 15.30 & 17.00 \\
\hline H1 & 1.60 & 1.54 & 26.36 & 20.31 & 19.38 & 17.23 & \\
\hline $\mathrm{H} 2$ & 1.93 & 1.86 & 27.30 & 23.14 & 22.10 & 18.45 & \\
\hline $\mathrm{H} 3$ & 1.41 & 1.27 & 24.94 & 21.84 & 17.38 & 18.61 & \\
\hline Al & 1.70 & 1.50 & 24.53 & 20.08 & 17.43 & 19.37 & \\
\hline A2 & 1.88 & 1.75 & 25.63 & 23.19 & 21.30 & 19.29 & \\
\hline $\mathrm{A} 3$ & 1.90 & 1.74 & 28.05 & 21.04 & 22.16 & 17.21 & \\
\hline N10 & & 1.81 & 1. 34 & 24.56 & 22.33 & 16.40 & 17.00 \\
\hline $\mathrm{H} 1$ & & 1.72 & 1.82 & 26.58 & 21.10 & 21.10 & 18.60 \\
\hline $\mathrm{H} 2$ & 1.83 & 1. 85 & 26.00 & 24.04 & 21.00 & 18.73 & \\
\hline H3 & 2.10 & 1.86 & 26.14 & 21.43 & 22.40 & 19.31 & \\
\hline A1 & 1.39 & 1.32 & 25.50 & 21.00 & 19.46 & 20.36 & \\
\hline A2 & 1.41 & 1.32 & 25.66 & 25.14 & 20.87 & 20.32 & \\
\hline A3 & 1.21 & 1.35 & 26.00 & 22.13 & 19.37 & 18.45 & \\
\hline L.S.D. $(0.05)$ & & 0.23 & 0.12 & 2.56 & 2.10 & 1.15 & 1.10 \\
\hline
\end{tabular}

N0, N5 and N10: nanosilver at 0, 5 and 10 ppm, respectively.H1, H2 and H3: humic acid at 200, 400 and 600 ppm, respectively. A1, A2 and A3: Aloe vera gel at $2.5 \%, 5.0 \%$ and $7.5 \%$ respectively. 
Table 4. Effect of nanosilver, humic acid and Aloe vera gel on total phenols in fresh leaves and petals of carnation cut flowers during two seasons.

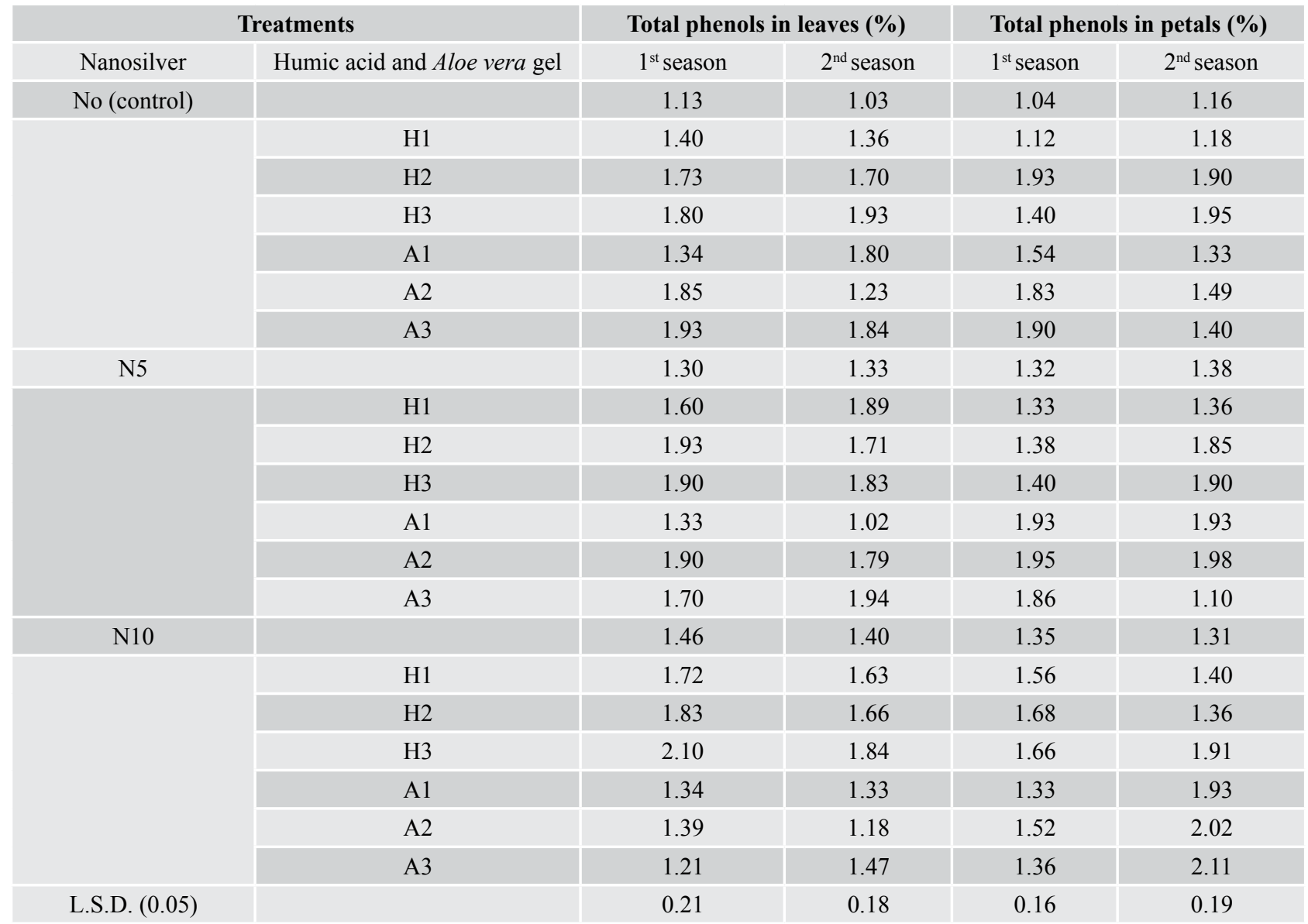

N0, N5 and N10: nanosilver at 0, 5 and 10 ppm, respectively.H1, H2 and H3: humic acid at 200, 400 and 600 ppm, respectively.A1, A2 and A3: Aloe vera gel at $2.5 \%, 5.0 \%$ and $7.5 \%$ respectively.

In this respect, it is obvious from the obtained data (Tables 1 and 2) that these treatments, especially $5 \mathrm{ppm}$ nanosilver $+5.0 \%$ Aloe vera gel were more effective for inducing increments in vase life and quality determinations of carnation cut flowers as well as decreasing bacterial count and suppressing bacterial growth.

The decrease in chlorophyll during senescence leads to accumulation of superoxide which is the precursor of reactive oxygen species (ROS) which damages the nucleic acids and oxidizes proteins, carbohydrates and lipids, and can lead to cell death (Anjum et al., 2015; Xie et al., 2015). Flowers preserved in vase solutions containing nanosilver exhibited higher chlorophyll content probably due to scavenge ROS by enzymatic and non-enzymatic pathways and production of secondary metabolites involved in free radical scavenging activity. High content of total phenols is associated with longer vase life. Accumulation of phenols overcomes biotic and abiotic stress in various flowers (Ahmad and Tahir, 2017). Phenols are also classified as non-enzymatic antioxidants which nullifies the toxic effect of free radicals (Das and Mandal, 2020). This agrees with previous study (Naing and Kim, 2020).

\section{Xylem vessel occlusion}

Xylem vessels of untreated flowering stems appeared to be blocked by mass of microorganisms (Figure 1). 


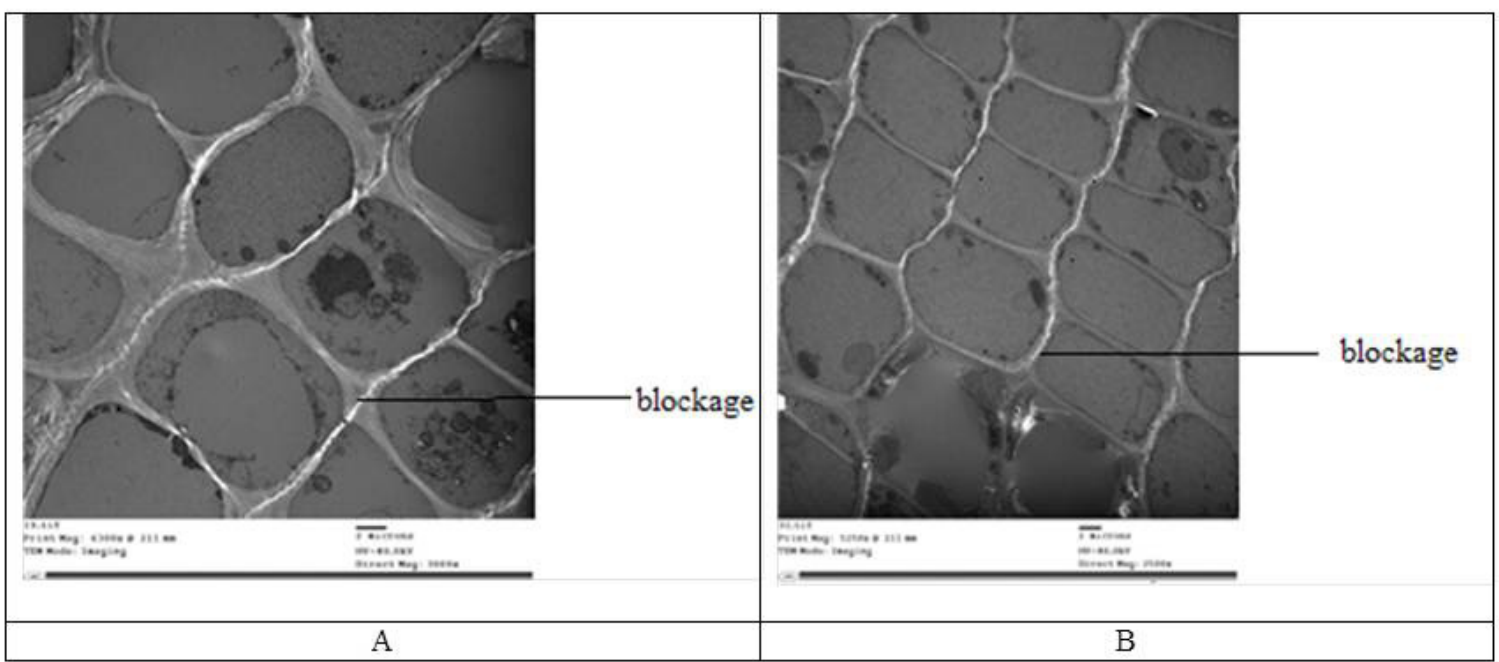

Figure 1. Ultrastructural identification of xylem vessel occlusion in the base of carnation flowering stem as affected with 5 ppm nanosilver $+5 \%$ Aloe vera gel. A: untreated control, B: treated with 5 ppm nanosilver $+5 \%$ Aloe vera gel. Bars $=200 \mu \mathrm{m}$.

The highest beneficial effects of the combined treatment on reducing blockage of xylem vessels was due to the synergetic effects of multiple modes of action of the components and mostly attributed to the apparent decrease of bacterial count in vase solution. Data indicated that the blockage of control xylem vessels was correlated with the highest bacterial count in vase solution and least vase life and supposed to be correlated with limiting the flowing of vase solution in flowering stems (Tables 1 and 2). Treatment of 5 ppm nanosilver $+5.0 \%$ Aloe vera gel was effective in reducing the blockage of xylem vessels of treated flowering stem comparing with the untreated control. In this concern, efficiency of nanosilver in inhibiting bacterial colonization and biofilm formation in xylem vessels, which are responsible for water translocation. Nanosilver succeeded as a biocide suppressing bacterial growth causing less vessel blockage in the flowering stems leading to promoting water uptake and decreasing water stress, and Aloe vera gel is a natural ingredient contains antiseptic agents against fungi, bacteria and viruses (Yagi et al., 2021).

\section{Anatomical studies}

The present anatomical study is restricted to the combined treatment of $5 \mathrm{ppm}$ nanosilver $+5.0 \%$ Aloe vera gel which exhibited more positive effects on the studied characters as mentioned before. It is clear from Table 5 and Figure 2 that applying the combined treatment of 5 ppm nanosilver $+5.0 \%$ Aloe vera gel resulted in larger diameter of the flowering stem than that of the untreated control.

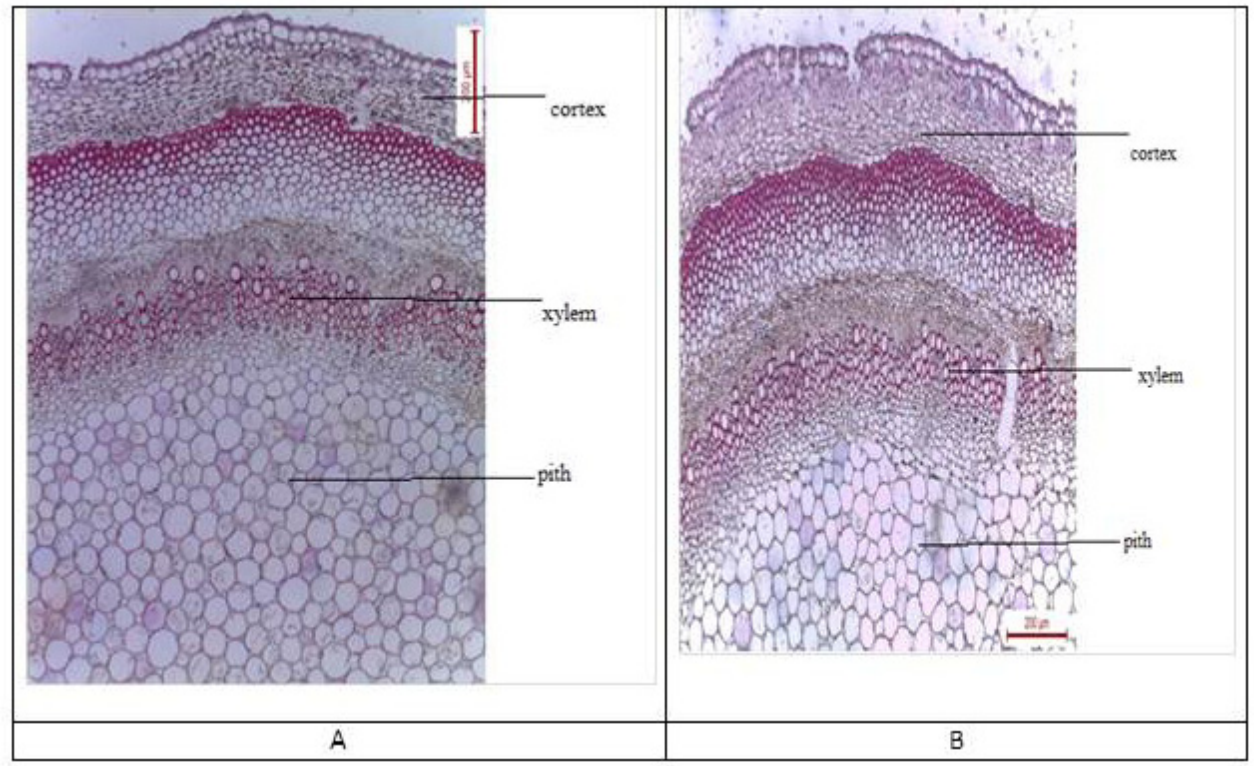

Figure 2. Transverse section in the base of the carnation flowering stem as affected with 5 ppm nanosilver $+5 \%$ Aloe vera gel. A: untreated control, B: treated with $5 \mathrm{ppm}$ nanosilver $+5 \%$ Aloe vera gel. Bars $=200 \mu \mathrm{m}$. 
Table 5. Mean values of some anatomical traits (in micron) in carnation flowering stem as affected with the combined treatment of 5 ppm nanosilver $+5 \%$ Aloe vera gel.

\begin{tabular}{|c|c|c|}
\hline Characters & Untreated control & $\begin{array}{c}\text { Treatment of 5 ppm nanosilver }+\mathbf{5 \%} \\
\text { Aloe vera } \text { gel }\end{array}$ \\
\hline Diameter of whole section $(\mu \mathrm{m})$ & 3092 & 4553 \\
\hline $\begin{array}{c}\text { Thickness of tissues outside the vascular } \\
\text { cylinder }(\mu \mathrm{m})\end{array}$ & 170 & 190 \\
\hline Thickness of the vascular cylinder $(\mu \mathrm{m})$ & 350 & 510 \\
\hline Diameter of xylem vessel $(\mu \mathrm{m})$ & 16 & 25 \\
\hline Diameter of pith $(\mu \mathrm{m})$ & 2052 & 3153 \\
\hline
\end{tabular}

It is obvious that the thickness of tissues outside the vascular cylinder, thickness of the vascular cylinder and diameter of the bith exhibited more positive response to the treatment compared with the control. Thus, the ability of the treatment to stimulate flowering stem diameter was attributed to the increase in thickness of the cortex thickness of the vascular cylinder and bith diameter. However the stimulative effect of the combined treatment was recognized in the ground meristem giving rise to cortex and bith. Also, the cambium activity was enhanced due to the treatment, since more conducting elements of phloem and xylem were produced and increased in size especially the vessels. This was responsible for the wider vascular cylinder. It is worth to note that the combined treatment of $5 \mathrm{ppm}$ nanosilver $+5.0 \%$ Aloe vera gel recorded the highest values of the studied anatomical traits of the flowering stem associated with highest values of both vase life and vase solution uptake as well as quality determinations. There is a positive relationship between cortex or bith and the capability of the storage cells to store water and food, leading to prolonging vase life. The increase in xylem and pith diameter emphasizes the high water uptake and food storage. Xylem vessel diameter is an indicator for efficient water conductivity that affects the duration of the postharvest life depending on the fact that the wide vessels are more efficient in water transport (Melvin and Zimmermann, 2002).

The positive changes in the structure of the treated flowering stem compared to the control might facilitate the transportation of more water, nutrients, minerals and metabolites throughout the flowering stem tissues. This might improve the quality of the treated cut flowers. However, the results obtained concerning the vase life vase solution uptake and quality determinations of cut flowers were in favor with this deduction.

\section{Conclusions}

According to the results obtained, it could be recommended to hold carnation cut flowers (Dianthus caryophyllus cv. Dover) in 5 ppm nanosilver $+5.0 \%$ Aloe vera gel vase solution to increase postharvest quality and vase life. Aloe vera gel, especially 5.0\% level, showed better results than humic acid when used alone or combined with nanosilver. Nanosilver at $5 \mathrm{ppm}$ recorded better results than $10 \mathrm{ppm}$ when used as a single treatment.

\section{Author Contribution}

ABESE: execution of the experiment, data collection, statistical analysis, writing and preparation of the manuscript. WRAS: experimental design, execution, data analysis and writing the manuscript

\section{Acknowledgments}

The authors would like to extend full thanks to Cairo University, Faculty of Agriculture for giving all facilities and apparatuses to complete present research

\section{References}

AALIFAR, M.; ALINIAEIFARD, S.; ARAB, M.; ZARE MEHRJERDI, M.; DIANATI DAYLAMI, S.; SEREK, M.; WOLTERING, E.; LI, T. Blue light improves vase life of carnation cut flowers through its effect on the antioxidant defense system. Frontiers in Plant Science, v.11, p.511, 2020. https://doi.org/10.3389/fpls.2020.00511

AHMAD, S.S.; TAHIR, I. Regulatory role of phenols in flower development and senescence in the genus Iris. Indian Journal of Plant Physiology, v.22, p. 135-140, 2017.

ANJUM, N.A.; SOFO, A.; SCOPA, A.; ROYCHOUDHURY, A.; GILL, S.S.; IQBAL, M.; LUKATKIN, A.S.; PEREIRA, E.; DUARTE, A.C.; AHMAD, I. Lipids and proteins-major targets of oxidative modifications in abiotic stressed plants. Environmental Science and Pollution Research, v.22, p.4099-4121, 2015.

BAYANATI, M.; AHMADINEJAD, E; KAZEMI, F.; RAHNAMA, H.; MOHAMADNIA, Z.; RAZAVI, K. Nanosilver/hydrogel: Synthesis and application in delaying senescence of cut flow. South African Journal of Botany, v.138, p.415-423, 2021. https://doi.org/10.1016/j. sajb.2021.01.018. 
BHARADWAJ,B.; VISHNUPRIYA, V.;BALAKRISHNA, R.N. Aloe vera - A review. Drug Invention Today, v.10, n.4, p.3704-3708. 2018.

BOXRIKER, M.; MÖHRING, J.; PIEPHO, H.P. Genetic and phenotypic correlation for breeding relevant traits in Dianthus caryophyllus L. Postharvest Biology and Technology, v.143, p.129-136, 2018.

BOZZOLA, J.J.; RUSSELL, L.D.; Electron Microscopy: Principles and Techniques for Biologists. Boston: Jones and Bartlett, 1999. 670p.

DARQUI, F.S.; RADONIC, L.M.; HOPP, H.; BILBAO, M.L. Biotechnological improvement of ornamental plants. Ornamental Horticulture, v.23, n.3, p.279-288, 2017. http://dx.doi.org/10.14295/oh.v23i3.1105

DAS, D.; MANDAL, P. Use of biogenic silver nanoparticles in enhancing shelf life of Morus alba L. at post-harvest stage. Scientific Reports, v.10, p.8923, 2020. https://doi. org/10.1038/s41598-020-65953-7

DUBOIS, M.; SMITH, F.; GILLES, K.A.; HAMILTON J.K.; REBERS, P.A. Colorimetric method for determination of sugar and related substances. Analytical Chemistry, v.28, n.3, p.350-356, 1956.

FAN, H.M.; LI, T.; SUN, X.; SUN, X.; ZHENG, C. Effects of humic acid derived from sediments on the postharvest vase life extension in cut chrysanthemum flowers. Postharvest Biology and Technology, v.101, p.82-87, 2015. https://doi.org/10.1016/j.postharvbio.2014.09.019

ISO 4833-1. Microbiology of the food chain. Horizontal method for the enumeration of microorganisms. Part 1: Colony count at 30 degrees $\mathrm{C}$ by the pour plate technique. Genebra: International Organization for Standardization, 2013. 9p

KAZEMIPOUR S.; HASHEMABADI, D.; KAVIANI, B.; MOHAMMADI, R. Effect of silver nanoparticles and sodium silicate on vase life and quality of cut chrysanthemum (Dendranthema grandiflorum L.) flower. Journal of Crop Production and Processing, v.5, n.18, p.63-74, 2016.

LI, H.; LI, H.; LIU, J.; LUO, Z.; JOYCE, D.; HE, S. Nano-silver treatments reduced bacterial colonization and biofilm formation at the stem-ends of cut gladiolus 'Eerde' spikes. Postharvest Biology and Technology, v.123, p.102-111, $2017 \mathrm{~b}$.

LI, W.; LACEY, R.F.; YE, Y.; LU, J.; YEH, K-C.; XIAO, Y.; LI, L.; WEN, C.K.; BINDER, B.M.; ZHAO,Y. Triplin, a small molecule, reveals copper ion transport in ethylene signaling from ATX1 to RAN1. PLoS Genetics, v.13, n.4, p.e1006703, 2017a. https://doi.org/10.1371/journal. pgen. 1006703
LITTLE, T.M.; HILLS, F.J. Agricultural Experimentation - design and analysis. New York: John Wiley \& Sons, Inc., 1978. 368p

MELVIN T.; ZIMMERMANN, M.H. Xylem structure and the ascent of sap. Berlin: Springer Verlag, 2002. 239p.

NAING, A.H.; KIM, C.K. Application of nano-silver particles to control the postharvest biology of cut flowers: A review. Scientia Horticulturae, v.270, p.109463, 2020. https://doi.org/10.1016/j.scienta.2020.109463

NAING, A.H.; WIN, N.M.; HAN, J.S.; LIM, K.B.; KIM, C.K. Role of Nano-silver and the bacterial Strain Enterobacter cloacae in increasing vase life of cut carnation 'Omea'. Frontiers in Plant Science, n.8, p.15901602, 2017. https://doi.org/10.3389/fpls.2017.01590

NAING, A.H.; WIN, N.M.; HAN, J.S.; LIM, K.B.; KIM, C.K. Role of nano-silver and bacterial strain Enterobacter cloacae in increasing vase life of cut carnation 'Omea'. Frontiers in Plant Science, v.8, p.1590-1602, 2017.

NASSAR, M.A.; EL-SAHHAR, K.F. Botanical Preparations and Microscopy (Microtechnique). Dokki: Academic Bookshop, 1998. 219p. (In Arabic).

NORNAI, R., Formula for determination of chlorophyll pigments extracted with N.N. dimethyl formamide. Plant Physiology, v.69, n.6, p.1376-1381, 1982.

PARK, D.Y.; NAING, A.H.; AI, T.N. ; HAN, J.S. ; KANG, I.K. ; KIM, C.K. Synergistic effect of nano-sliver with sucrose on extending vase life of the carnation cv. Edun. Frontiers in Plant Science, n.8, p.1601, 2017. https://doi. org/10.3389/fpls.2017.01601.

QING, Y.; CHENG, L.; LI, R.; LIU, G.; ZHANG, Y.; TANG, X., WANG, J.; LIU, H. ; QIN, Y. Potential antibacterial mechanism of silver nanoparticles and the optimization of orthopedic implants by advanced modification technologies. International journal of nanomedicine, v.5, n.13, p. 33113327, 2018. https://doi.org/10.2147/IJN.S165125

RASHIDIANI, N.; NAZARI, F.; JAVADI, T.; SAMADI, $\mathrm{S}$. Comparative postharvest responses of carnation and chrysanthemum to synthesized silver nanoparticles (AgNPs). Advances in Horticultural Science, v.34, n.2, p.133-145, 2020. https://doi.org/10.13128/ahsc-7491

SCHALLER, G.E.; BINDER, B.M. Inhibitors of ethylene biosynthesis and signaling. In: BINDER, B.; SCHALLER, G.E. (eds). Ethylene Signaling. Methods in Molecular Biology, New York: Humana Press, 2017. p.223-235. 
SCHOUTEN, R.E.; VERDONK, J.C.; MEETEREN, $\mathrm{U}$. Re-evaluating the role of bacteria in gerbera vase life. Postharvest Biology and Technology, v.143, p.1-12, 2018. SHOKALU, A.O.; AKINTOYE, H.A.; OLATUNJI, M.T.; ADEBAYO, A.G.; JAMES, I.E. Use of organic and inorganic solutions for extending the vase life of cut Heliconia 'Golden Torch' flowers. Acta Horticulture, n.1263, p.497-502, 2019. https://doi.org/10.17660/ ActaHortic.2019.1263.64

SINGLETON, V.L.; ROSSI, J.A. Colorimetry of total phenolics with phosphomolybdic-phosphotungstic acid reagents. American Journal Enology and Viticulture, v.16, p.144-158, 1965.

VEHNIWAL, S.S.; ABBEY L. Cut flower vase life influential factors, metabolism and organic formulation. Horticulture International Journal. v.3, n.6, p.275-21, 2019. https://doi.org/10.15406/hij.2019.03.00142

WANG, L.; Hu, C.; SHAO L. The antimicrobial activity of nanoparticles: present situation and prospects for the future. International Journal of Nanomedicine, v.12, p.1227-1249, 2017. https://doi.org/10.2147/IJN.S121956
WU, L., MA, N., JIA, Y., ZHANG, Y., FENG, M., JIANG, C.Z., MA, C., GAO, J. An ethylene-induced regulatory module delays flower senescence by regulating cytokinin content. Plant Physiology, v.173, n.1, p.853-862, 2017. https://doi.org/10.1104/pp.16.01064

XIE, Q.; MICHAELI, S.; PELED-ZEHAVI, H. GALILI, G. Chloroplast degradation: one organelle, multiple degradation pathways. Trends Plant Science, v.20, p.264265, 2015.

YAGI, A.; ATAKA, S.; YU, B.P. Putative roles of aloe ingredients in aging and age-related diseases: management of microbiota seno inflammatory process. Journal of Gastroenterology and Hepatology Research, v.10, n.2, p.3460-3465, 2021.

YAGI, M.; SHIRASAWA, K.; HIRAKAWA, H.; ISOBE, S.; MATSUNO, J.; UNO, Y.; YAMAGUCHI, H. QTL analysis for flowering time in carnation (Dianthus caryophyllus L.). Scientia Horticulturae, v.262, p.109053, 2020. https://doi.org/10.1016/j.scienta.2019.10905 